\title{
UPAYA MENGURANGI WAKTU IDLE MESIN POTONG OTOMATIS MEREK GERBER TIPE XLc7000
}

\author{
AN EFFORT TO DECREASE THE IDLE TIME OF AUTOMATIC \\ CUTTING MACHINE GERBER TYPE XLC7000
}

\author{
Saifurohman ${ }^{1}$, Ursae Pramesvari ${ }^{2}$ \\ ${ }^{1}$ Instruktur Ahli Pertama, Produksi Garmen, Politeknik STTT, Bandung, 40272, \\ Indonesia \\ ${ }^{2}$ Instruktur Ahli Pertama, Produksi Garmen, Politeknik STTT, Bandung, 40272, \\ Indonesia \\ E-mail : saifurohmannn@gmail.com, ursaepramesvari@gmail.com
}

\begin{abstract}
ABSTRAK
Dalam dunia industri saat ini, mesin-mesin otomatis telah banyak digunakan dengan tujuan untuk meningkatkan produktifitas industri tersebut. PT TWI merupakan salah satu industri yang telah menggunakan mesin-mesin otomatis dalam proses produksinya. Berdasarkan hasil pengamatan yang dilakukan di bagian Cutting PT TWI, diketahui terdapat mesin potong otomatis Gerber, namun dalam penggunaannya tidak maksimal sehingga menyebabkan tingginya waktu idle mesin tersebut. Terdapat beberapa proses pengerjaan yang seharusnya dapat dilakukan secara bersamaan atau bahkan dihilangkan, namun pada kenyataannya tidak dilakukan. Untuk itu, diterapkan perbaikan dengan cara menghilangkan beberapa proses dan menggabungkan atau melakukan beberapa proses secara bersamaan, terutama pada proses-proses yang menyebabkan waktu idle menjadi tinggi. Hasil dari perbaikan ini didapatkan waktu idle mesin potong yang lebih rendah, yaitu 3.827,24 detik atau 63,79 menit, yang awalnya sebesar 4.821,9 detik atau 80,37 menit. Meskipun tidak dapat menghilangkan waktu idle mesin secara keseluruhan, namun waktu idle dapat diturunkan cukup besar, yaitu sebesar 994,66 detik atau 16,58 menit.
\end{abstract}

Kata Kunci : Mesin potong otomatis Gerber, waktu idle

\begin{abstract}
In industrial world, automated machines have been widely used with the aim of increasing the productivity of the industry. PT TWI is one of the industries that has used automated machines in its production process. Based on the result of observations made at the Cutting Department PT TWI. It can be seen that the use of automatic cutting Gerber machine is not maximized which cause high idle time. There are several processes that should be done simultaneously or even eliminated, but not implemented. So that, we applied the improvement by doing several processes simultaneously, especially for the processes that cause the idle time to be high. The results of this improvement obtained a lower idle time, which is 3.827,24
\end{abstract}


seconds or 63,79 minutes, which initially amounted to $4.821,9$ seconds or 80,37 minutes. The idle time drops by 994,66 seconds or 16,58 minutes, the decline time is quite large, although it can not simultaneously eliminate the idle time of the machine.

Keywords: Automatic cutting machine Gerber, Idle time

\section{PENDAHULUAN}

Berdasarkan pengamatan yang dilakukan di bagian Cutting PT TWI, dapat diketahui penggunaan mesin potong otomatis Gerber tidak dimaksimalkan sehingga menyebabkan waktu idle dari mesin lebih banyak dibandingkan waktu penggunaannya.

Hal ini disebabkan karena beberapa hal, diantaranya :

a. Proses pemotongan yang tidak berkelanjutan. Proses pemotongan panel untuk bite berikutnya harus menunggu proses bundling selesai, karena pada saat mesin selesai memotong panel dalam 1 bite, operator belum selesai membundling panel hasil pemotongan bite sebelumnya.

Bite adalah grup atau porsi yang akan dipotong secara bertahap dalam 1 marker, 1 bite terdiri dari beberapa pieces panel (dapat dilihat pada gambar $1 \mathrm{di}$ bawah ini).

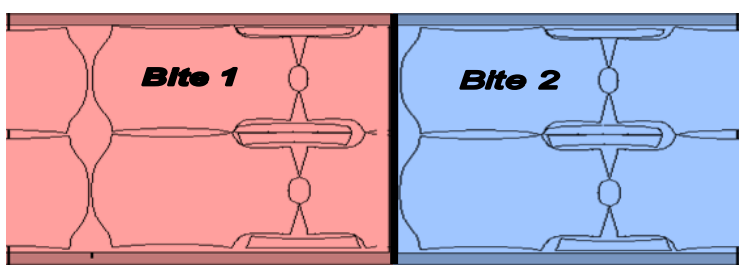

Gambar 1. Bite (Grup) Pemotongan dalam Marker

b. Perpindahan mesin ke meja berikutnya harus menunggu proses bundling selesai, sehingga proses persiapan kain yang akan dipotong di meja berikutnya juga harus menunggu.

Maksud dari penelitian ini adalah untuk meningkatkan efektifitas mesin potong otomatis Gerber (gambar mesin potong otomatis Gerber dapat dilihat pada gambar 2) melalui perbaikan sistem kerja pada proses pemotongan, dengan cara menghilangkan beberapa proses dan menggabungkan atau melakukan beberapa proses secara bersamaan. Diantaranya, proses bundling dimulai pada saat mesin potong selesai memotong panel dalam 
1 bite, serta proses bundling dilakukan bersamaan dengan perpindahan mesin dan proses persiapan kain yang akan dipotong di meja berikutnya.

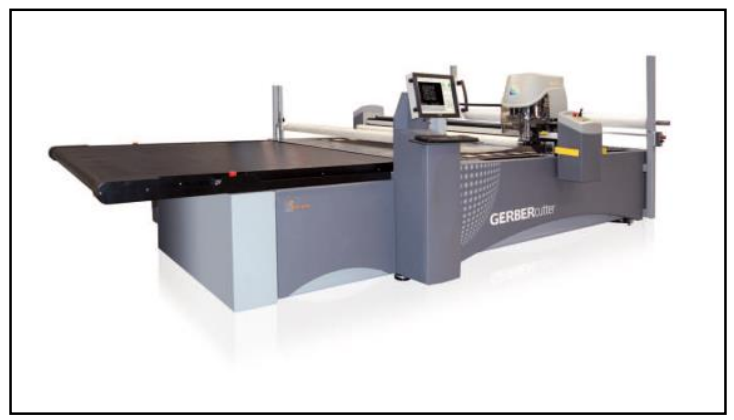

Gambar 2. Mesin Potong Otomatis Gerber Tipe XLc7000 (Automatic Cutter)

\section{Waktu Idle}

Waktu idle atau Idle time (waktu menganggur) adalah waktu ketika sebuah pekerjaan berguna yang seharusnya bisa dilakukan tetapi tidak dilakukan. Atau bisa juga diartikan sebagai durasi waktu di saat sebuah peranti / alat / mesin dalam kondisi statis. Dengan kata lain peranti itu hidup tetapi tidak dipakai untuk bekerja.

Salah satu cara yang dapat dilakukan oleh perusahaan untuk mendapatkan keuntungan yang maksimal, adalah dengan mengeluarkan biaya seminimum mungkin, dan memaksimalkan kerja pegawai ataupun juga bisa dengan cara memaksimalkan kerja mesin dengan tujuan meminimalkan waktu idle mesin. Tingginya waktu idle mesin yang berarti efektifitas mesin rendah akan menyebabkan kerugian bagi perusahaan. Salah satu faktor penyebab terjadinya proses produksi yang tidak bisa maksimal adalah penggunaan mesin yang tidak optimal dalam proses produksi.

Beberapa faktor penyebab idle time diantaranya:

a. Keterlambatan saat mulai kerja.

b. Menunggu proses sebelumnya.

c. Proses perpindahan mesin.

d. Menunggu kedatangan material.

e. Menunggu perbaikan alat.

\section{METODE PENELITIAN}

Untuk memperoleh data yang diperlukan, maka penelitian dilakukan dengan beberapa cara :

1. Studi Pustaka

Studi pustaka diperoleh dari penelitian mahasiswa, buku-buku yang terdapat di perpustakaan Politeknik STTT Bandung, dan juga dari internet.

2. Studi lapangan, meliputi :

- Melakukan

pengamatan langsung terhadap proses pemotongan menggunakan mesin potong otomatis Gerber 
di bagian Cutting PT TWI untuk order T-shirt Style $W$ Train Tee dengan bahan polyester mesh $120 \mathrm{gsm}$.

- Melakukan pengukuran waktu dan pengumpulan data mulai dari persiapan pemotongan, pada saat proses pemotongan dan setelah pemotongan.

- Melakukan wawancara langsung dengan pihak-pihak yang berhubungan dengan proses pemotongan di bagian cutting, seperti cutting manager, supervisor, operator spreading, operator cutting, operator bundling, dan juga bagian IE (Industrial Engineering).

3. Melakukan percobaan dengan tahapan-tahapan :

- Menyusun langkah-langkah perbaikan sistem kerja di bagian cutting, pada saat proses pemotongan dan bundling.

- Menetapkan metode sistem kerja dengan menghilangkan beberapa proses dan menggabungkan atau melakukan beberapa proses secara bersamaan, dalam upaya mengurangi waktu idle mesin potong otomatis Gerber di bagian cutting.

- Melakukan evaluasi terhadap hasil perbaikan sistem kerja dengan menghitung dan membandingkan waktu idle mesin potong otomatis Gerber sebelum dan setelah dilakukan perbaikan.

\section{HASIL DAN PEMBAHASAN}

\subsection{Pelaksanaan Pengamatan}

Pengamatan dilakukan di Departemen Pemotongan (Cutting) PT TWI pada proses gelar susun, pemotongan menggunakan mesin potong otomatis Gerber, dan pembundelan (bundling) untuk order T-shirt Style W Train Tee dengan bahan polyester mesh 120 gsm. Maksud dari pengamatan ini adalah untuk mengetahui seberapa besar pengaruh sistem kerja yang diterapkan perusahaan terhadap waktu idle mesin potong otomatis Gerber pada proses pemotongan untuk order T-shirt Style W Train Tee.

Pengamatan dilakukan pada $2 x$ pemotongan marker untuk mengetahui berapa lama waktu idle antara pemotongan marker pertama dan 
marker kedua. Waktu idle antar marker inilah yang akan dilakukan perbaikan.

Pengamatan dilakukan dengan cara mengukur waktu mulai dari proses gelar susun kain, proses pemotongan dengan mesin potong otomatis Gerber, dan proses bundling. Berikut ini adalah proses-proses pengukuran waktu yang dilakukan:

1. Proses Gelar Susun (Spreading)

Pengukuran waktu proses gelar susun dilakukan pada operator gelar di meja penggelaran, proses penggelaran dilakukan dengan mesin gelar otomatis. Pengukuran dilakukan dalam $2 x$ pemotongan, dengan total kain per-marker yang digelar adalah sebanyak 100 lembar kain.

2. Proses Pemotongan (Cutting) Sebelum proses pemotongan dilakukan, tumpukan kain harus digeser masuk ke dalam mesin potong dan diberi lembaran plastik polyethylene di atas tumpukan kain sebagai penutup. Fungsi pemberian plastik sebagai penutup adalah untuk menciptakan ruang hampa sehingga kain dapat dihisap oleh vacuum pada mesin potong otomatis.

Pengukuran waktu dilakukan dalam 2x pemotongan marker. Proses pemotongan dilakukan sebanyak $3 x$ dalam $1 x$ pemotongan marker. Hal ini dikarenakan pemotongan dengan mesin potong otomatis Gerber untuk order T-shirt Style $W$ Train Tee dipotong dalam 3 bite. Satu siklus pemotongan menggunakan mesin potong otomatis Gerber adalah 1 bite.

3. Proses Pembundelan (Bundling) Proses bundling dilakukan pada off table mesin potong Gerber segera setelah panel-panel dipotong pada tiap bite. Pengukuran waktu untuk proses bundling dilakukan pada operator bundling, yang diukur mulai dari pengambilan panel, bundling panel, sampai panel disimpan / diletakkan.

Pengukuran waktu dilakukan dalam $2 x$ pemotongan marker. Untuk setiap pemotongan 1 marker, dilakukan pengukuran sebanyak $3 x$, dengan rincian $1 x$ pengukuran waktu dilakukan untuk panel-panel yang dipotong dalam 1 bite. 


\subsection{Pengamatan Awal pada Proses Pemotongan Menggunakan Mesin Potong Otomatis Gerber}

Berdasarkan pengamatan yang sudah dilakukan pada proses pemotongan, pengamatan dilanjutkan dengan mengidentifikasi tingginya waktu idle mesin potong Gerber yang hanya dilihat dari faktor metode saja, karena pada proses pemotongan dengan mesin potong Gerber khususnya pada pemotongan untuk order T-shirt Style W Train Tee terjadi pemborosan waktu dan waktu tunggu untuk proses selanjutnya yang disebabkan karena proses sebelumnya belum selesai. Identifikasi tingginya waktu idle yang dilihat dari faktor metode disajikan pada Gambar 3.

Berikut ini adalah penjelasan dari diagram sebab akibat mengenai identifikasi tingginya waktu idle mesin potong otomatis Gerber:

1. Adanya proses yang tidak seimbang, yaitu antara proses pemotongan dengan proses bundling, hal ini mengakibatkan proses pemotongan pada bite selanjutnya harus menunggu proses bundling selesai.

2. Proses bundling pada bite kedua seharusnya dilakukan secara bersamaan dengan pemotongan bite terakhir dan bergesernya mesin ke meja berikutnya sehingga proses persiapan kain sebelum pemotongan juga dapat dilakukan selama proses bundling bite terakhir berlangsung.

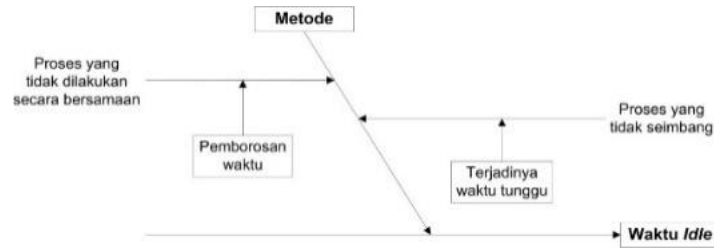

Gambar 3. Diagram Sebab Akibat Identifikasi Tingginya Waktu Idle

3.3 Upaya Membuat Metode Perbaikan Sistem Kerja Pada Proses Cutting dan Bundling

Dalam upaya menurunkan waktu idle mesin potong otomatis Gerber, maka perlu dilakukan perbaikan pada sistem kerja di bagian pemotongan. Perbaikan sistem kerja dapat dilakukan dengan cara menghilangkan proses-proses yang tidak perlu, menggabungkan suatu proses dengan proses lainnya, atau menemukan suatu urutan-urutan proses produksi yang lebih baik, sehingga waktu idle dapat dikurangi.

Berdasarkan hasil identifikasi tingginya waktu idle mesin potong Gerber pada 
faktor metode di atas, maka perlu dilakukan adanya upaya perbaikan untuk mengurangi waktu idle mesin potong otomatis Gerber. Adapun upaya perbaikan yang dilakukan adalah sebagai berikut:

1. Proses bundling dilakukan segera setelah mesin selesai memotong panel dalam 1 bite. Persiapan bundling seperti tali untuk bundle dipersiapkan selama mesin sedang memotong panel, sehingga ketika mesin selesai memotong, operator sudah siap untuk melakukan bundling. Upaya perbaikan untuk persiapan proses bundling dapat dilihat pada gambar 4 di bawah ini.
2. Lingkaran merah pada gambar sebelum perbaikan menunjukkan operator mempersiapkan tali untuk bundling setelah proses pemotongan selesai. Sedangkan lingkaran merah pada gambar sesudah perbaikan menunjukkan tali untuk bundling sudah dipersiapkan sebelumnya, yaitu selama proses pemotongan berlangsung, sehingga pada saat proses pemotongan selesai proses bunding dapat segera dilakukan.

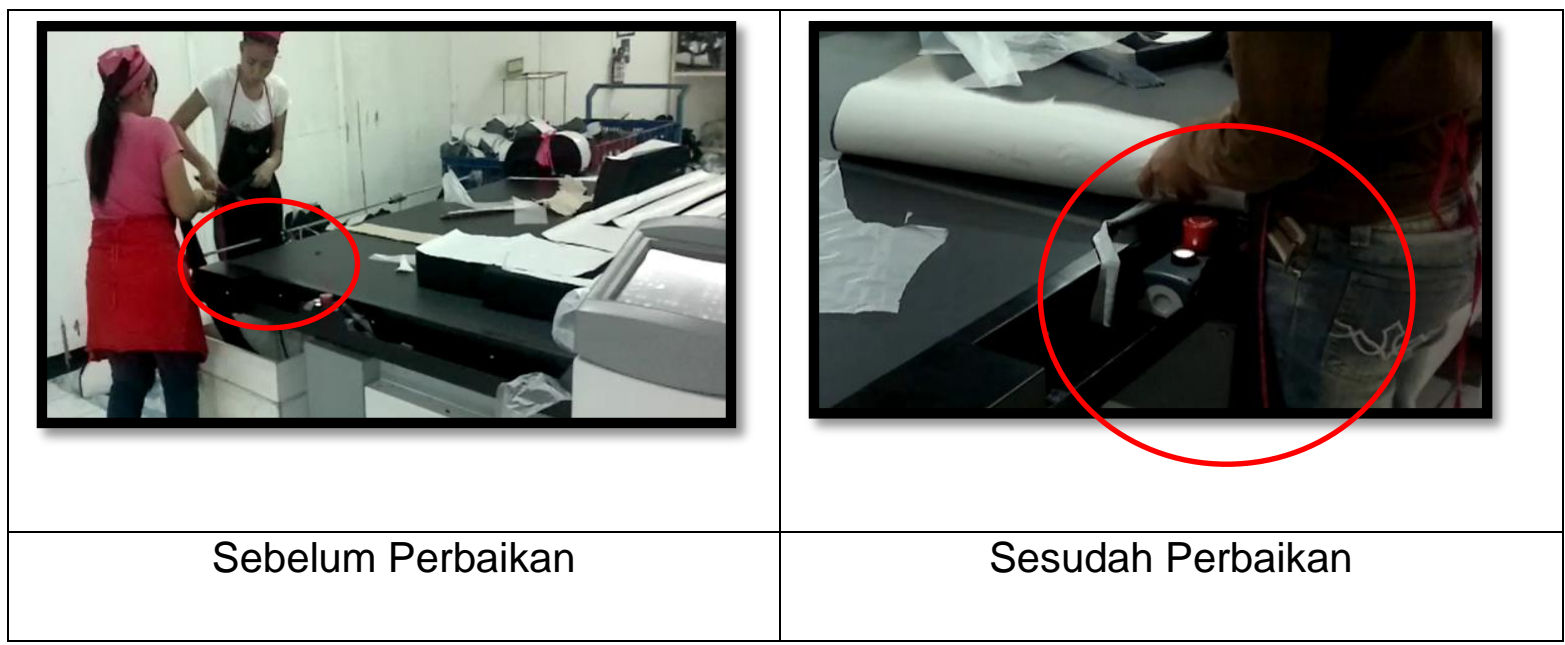

Gambar 4. Perbaikan Sistem Kerja pada Persiapan Bundling 
3. Proses bundling untuk bite kedua dilakukan bersamaan dengan pemotongan bite terakhir dan pergeseran mesin ke meja berikutnya, sehingga proses persiapan kain untuk pemotongan marker kedua juga dapat dilakukan selama proses bundling bite terakhir berlangsung. Upaya perbaikan pada proses bundling dan persiapan kain untuk pemotongan dapat dilihat pada gambar 5 di bawah ini. Lingkaran dan tanda panah berwarna merah pada gambar sebelum perbaikan menunjukkan proses bundling hasil potongan bite terakhir tidak dilakukan secara bersamaan dengan pergeseran mesin dan persiapan kain untuk pemotongan marker berikutnya. Sedangkan lingkaran dan tanda panah berwarna merah pada gambar sesudah perbaikan menunjukkan adanya perbaikan berupa proses bundling hasil pemotongan bite terakhir yang dilakukan secara bersamaan dengan pergeseran mesin dan persiapan kain untuk pemotongan marker berikutnya.

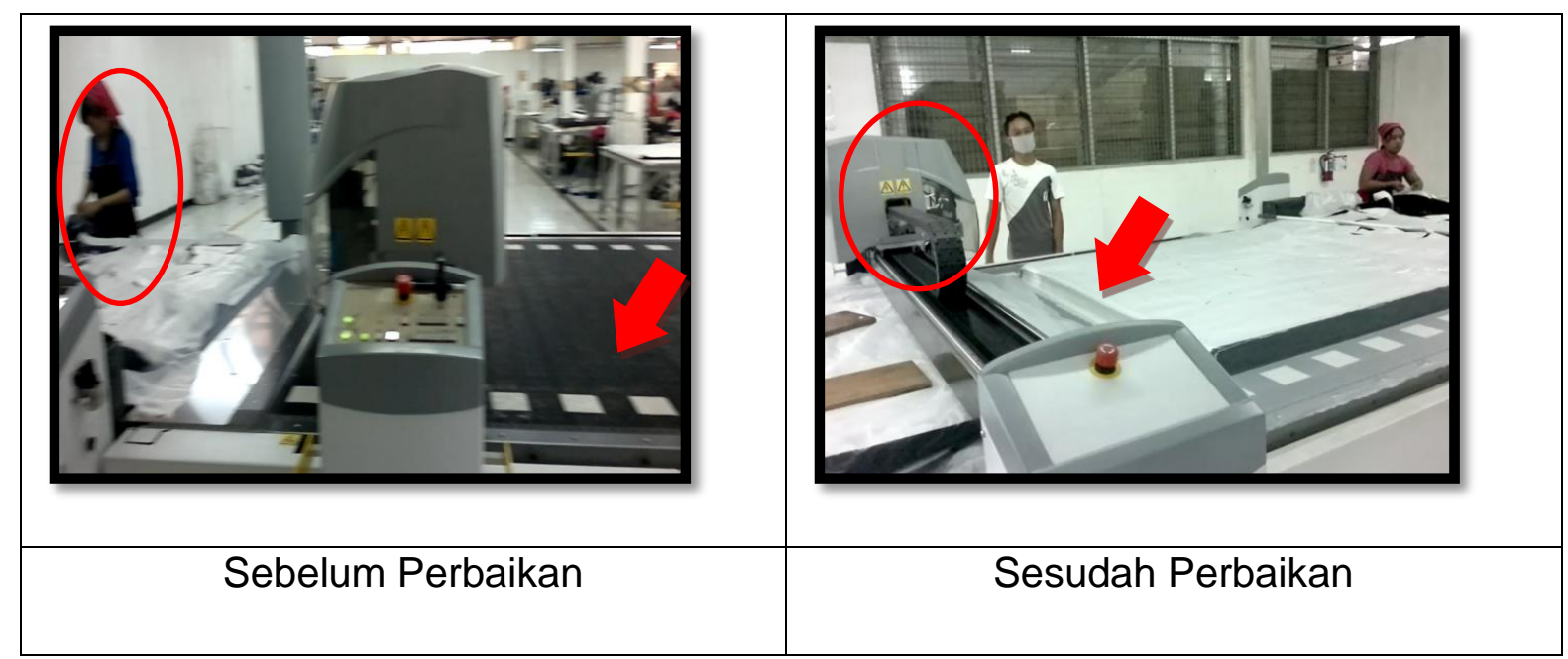

Gambar 5. Perbaikan Pada Proses Bundling dan Persiapan Kain untuk Pemotongan 


\subsection{Hasil Penerapan Sistem Kerja} Terhadap Tingginya Waktu Idle Mesin Potong Otomatis Gerber di Bagian Cutting

Setelah dilakukan perbaikan sistem kerja pada bagian pemotongan, yaitu pada proses persiapan bundling, proses bundling dan persiapan kain untuk pemotongan, dapat diketahui penurunan waktu idle mesin potong otomatis Gerber yang didapatkan dari perbandingan waktu idle sebelum dilakukan perbaikan dan sesudah dilakukan perbaikan sistem kerja.

Data perbandingan ini ditunjukkan melalui data waktu perusahaan hasil dari pengukuran waktu mulai dari proses gelar susun (spreading) sampai dengan proses bundling dan pergeseran mesin. Data perbandingan dapat dilihat pada Tabel 1 dan 2 di bawah ini.
Tabel 1. Pengelompokan Data

Waktu Perusahaan Sebelum

Perbaikan

\begin{tabular}{|l|l|r|}
\hline No. & Keterangan Waktu & \multicolumn{1}{|c|}{$\begin{array}{l}\text { Waktu } \\
\text { (detik) }\end{array}$} \\
\hline 1 & $\begin{array}{l}\text { Waktu persiapan } \\
\text { penggelaran }\end{array}$ & 334,65 \\
\hline 2 & Waktu penggelaran & $1.492,81$ \\
\hline 3 & $\begin{array}{l}\text { Waktu proses akhir } \\
\text { penggelaran }\end{array}$ & 155,25 \\
\hline 4 & $\begin{array}{l}\text { Waktu persiapan } \\
\text { pemotongan }\end{array}$ & 570,90 \\
\hline 5 & Waktu pemotongan & $4.674,75$ \\
\hline 6 & $\begin{array}{l}\text { Waktu persiapan } \\
\text { bundling }\end{array}$ & 63,44 \\
\hline 7 & Waktu bundling & $5.072,82$ \\
\hline 8 & $\begin{array}{l}\text { Waktu pergeseran } \\
\text { mesin }\end{array}$ & 161,69 \\
\hline 9 & Waktu Idle \\
\hline
\end{tabular}

Dari Tabel 1 di atas dibuat grafik batang untuk masing-masing waktunya agar memudahkan dalam memahami data tersebut. Berikut ini adalah grafik batang dari masing-masing waktu berdasarkan Tabel 1. 


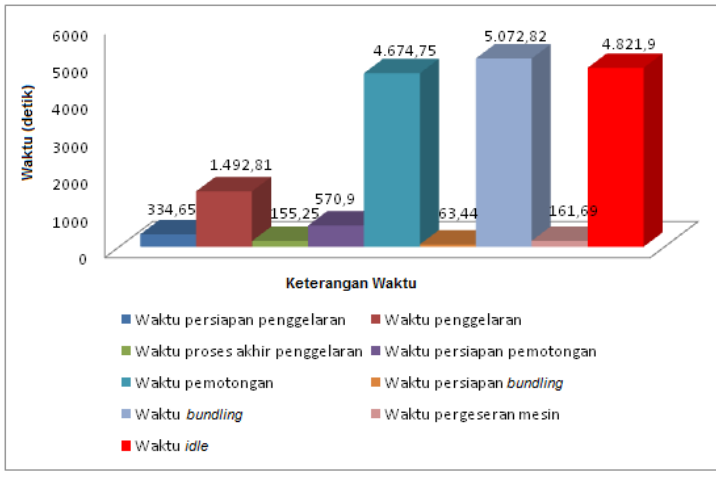

Gambar 6. Grafik Pengelompokan

Data Waktu Perusahaan Sebelum

Perbaikan

Tabel 2. Pengelompokan Data

Waktu Perusahaan Setelah

Perbaikan

\begin{tabular}{|l|l|r|}
\hline No. & Keterangan Waktu & \multicolumn{1}{|l|}{$\begin{array}{l}\text { Waktu } \\
\text { (detik) }\end{array}$} \\
\hline 1 & $\begin{array}{l}\text { Waktu persiapan } \\
\text { penggelaran }\end{array}$ & 345,99 \\
\hline 2 & Waktu penggelaran & $1.492,81$ \\
\hline 3 & $\begin{array}{l}\text { Waktu proses akhir } \\
\text { penggelaran }\end{array}$ & 158,31 \\
\hline 4 & $\begin{array}{l}\text { Waktu persiapan } \\
\text { pemotongan }\end{array}$ & 282,83 \\
\hline 5 & Waktu pemotongan & $4.669,49$ \\
\hline 6 & $\begin{array}{l}\text { Waktu persiapan } \\
\text { bundling }\end{array}$ & 68,15 \\
\hline 7 & Waktu bundling & $5.068,55$ \\
\hline 8 & $\begin{array}{l}\text { Waktu pergeseran } \\
\text { mesin }\end{array}$ & 159,30 \\
\hline 9 & Waktu Idle & $3.827,24$ \\
\hline
\end{tabular}

Pada Gambar 6 dapat dilihat tingginya waktu idle pada proses pemotongan yang diakibatkan oleh proses-proses yang seharusnya dapat dilakukan secara bersamaan namun pada kenyataannya tidak dilakukan.

Dari Tabel 2 dibuat grafik batang untuk masing-masing waktunya agar memudahkan dalam memahami data tersebut. Berikut ini adalah grafik batang dari masing-masing waktu setelah perbaikan berdasarkan Tabel 2.

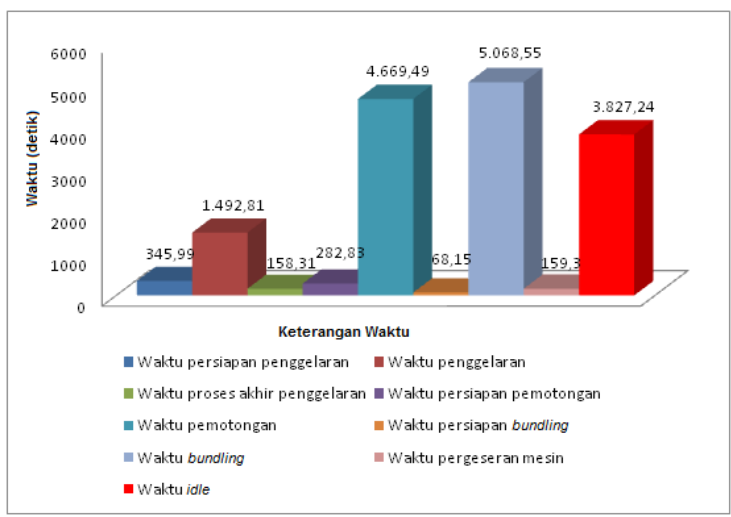

\section{Gambar 7. Grafik Pengelompokan Data Waktu Perusahaan Setelah Perbaikan}

Dari Gambar 7 di atas, dapat dilihat turunnya waktu idle yang diakibatkan oleh proses persiapan bundling, proses bundling yang terlalu lama dan 
pergeseran mesin, dibandingkan waktu idle mesin sebelum dilakukan perbaikan sistem kerja dengan cara

\subsection{Pembahasan}

Perbaikan sistem kerja di Departemen Cutting untuk order T-shirt Style W Train Tee dilakukan dengan mengidentifikasi terlebih dahulu pada proses mana saja yang terdapat pemborosan, dengan memperhatikan kemampuan operator dalam melaksanakan operasi tersebut. Setelah itu dibuat peta pekerja-mesin untuk mempermudah menganalisis dan memperbaiki sistem kerja.

Sebelum pengaturan perbaikan sistem kerja, proses bundling tidak dilakukan secara bersamaan dengan mesin ketika selesai memotong panel dalam 1 bite. Tetapi setelah dilakukan perbaikan sistem kerja, operator melakukan proses bundling bersamaan dengan mesin ketika selesai memotong panel dalam 1 bite. Operator melakukan persiapan bundling seperti tali untuk bundle pada saat mesin sedang memotong panel pada bite pertama, sehingga setelah mesin selesai memotong panel bite pertama, operator dapat segera melakukan bundling. Selain itu juga menggabungkan beberapa proses kerja.

dapat kita lihat proses bundling untuk bite kedua dilakukan bersamaan dengan pemotongan panel pada bite terakhir dan pergeseran mesin ke meja gelar berikutnya. Sehingga pada proses bundling bite terakhir dapat dilakukan bersamaan dengan proses persiapan kain untuk pemotongan berikutnya. Perbaikan sistem kerja ini dilakukan untuk menyeimbangkan proses bundling dengan proses pemotongan agar mengurangi waktu tunggu karena bundling belum selesai, sehingga waktu menganggur (idle) mesin potong Gerber yang diakibatkan oleh proses bundling dapat dikurangi.

Waktu idle mesin dihitung dari jarak antar pemotongan, semakin lama jarak antar pemotongan, semakin tinggi waktu idle dari mesin. Hal ini tentunya akan berpengaruh juga terhadap output dan pencapaian target produksi Departemen Cutting PT. TWI.

Waktu idle yang dibahas, dihitung dan dilakukan perbaikan pada pengamatan ini adalah waktu idle yang disebabkan oleh proses persiapan penggelaran, proses penggelaran, persiapan 
pemotongan, persiapan bundling dan proses bundling. Waktu idle yang disebabkan oleh selain faktor-faktor di atas seperti mesin rusak, dan menunggu kedatangan material diabaikan.

Waktu idle pada pengamatan ini adalah waktu idle pada awal pertama kali pemotongan dan waktu idle antar pemotongan, yaitu pemotongan marker ke-1 dan marker ke-2. Waktu proses pada awal pemotongan dihitung sebagai waktu idle mesin, jadi waktu proses persiapan penggelaran, proses penggelaran, proses akhir penggelaran, dan proses persiapan pemotongan termasuk ke dalam waktu idle. Waktu idle yang paling tinggi dan tidak dapat dihindari adalah waktu idle pada saat awal pemotongan seperti proses persiapan penggelaran, proses penggelaran, proses akhir penggelaran, dan proses persiapan pemotongan. Namun, untuk waktu idle antar pemotongan marker dapat diturunkan dengan perbaikan sistem kerja.

Pada perbaikan sistem kerja yang dilakukan, waktu persiapan bundling dilakukan secara bersamaan dengan proses pemotongan bite 1, sehingga proses bundling dapat dimulai pada saat mesin potong selesai memotong bite 1. Proses bundling juga dilakukan secara bersamaan dengan perpindahan mesin ke meja berikutnya dan persiapan pemotongan, hal ini akan membuat jarak antar pemotongan menjadi berkurang, sehingga waktu idle mesin juga akan berkurang.

Dengan menggabungkan beberapa proses secara bersamaan, maka proses persiapan bundling, proses perpindahan mesin, dan proses persiapan pemotongan dapat kita anggap tidak ada, karena proses pengerjaannya dilakukan secara bersamaan dengan proses pemotongan dan proses bundling. Perbandingan waktu idle sebelum dan sesudah dilakukan perbaikan disajikan dalam bentuk skema waktu proses pada Departemen Cutting yang dimulai dari proses penggelaran dan persiapan pemotongan sampai pada perpindahan mesin ke meja berikutnya. Skema waktu proses pada Departemen Cutting disajikan pada Gambar 8.

Pada Gambar 8, sebelum dilakukan perbaikan terdapat 16 (enam belas) proses yang menjadi penyebab waktu idle. Dari enam belas proses tersebut, ada beberapa yang dapat kita 
gabungkan atau dilakukan secara bersamaan dengan proses lainnya.

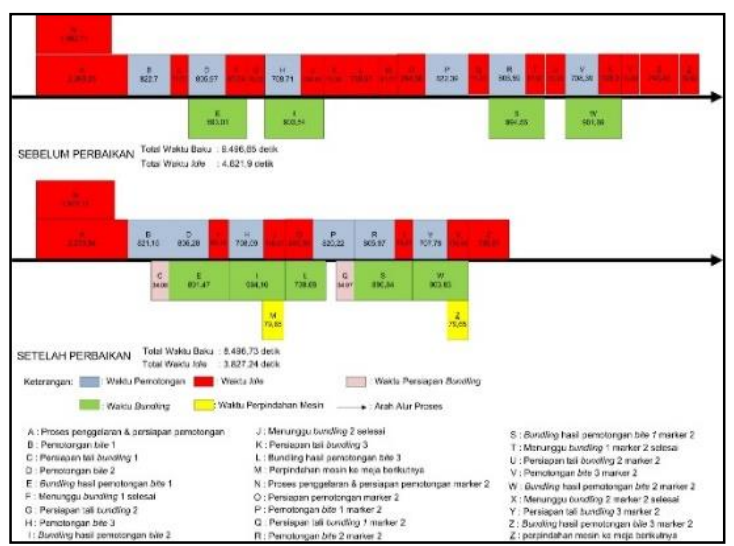

Gambar 8. Skema Waktu Proses pada Departemen Cutting Sebelum dan Setelah Perbaikan

Setelah dilakukan perbaikan sistem kerja, yaitu dengan cara melakukan beberapa proses secara bersamaan, didapatkan waktu idle yang lebih rendah. Penyebab waktu idle yang awalnya terdapat 16 (enam belas) proses, setelah perbaikan hanya tinggal 7 (tujuh) proses yang menyebabkan waktu idle.

Waktu idle sebelum dilakukan perbaikan adalah 4.821,9 detik atau 80,365 menit. Setelah dilakukan perbaikan sistem kerja, waktu idle mesin turun sebanyak 994,66 detik atau 16,58 menit menjadi $3.827,24$ detik atau 63,79 menit.

\section{KESIMPULAN}

Berdasarkan hasil pengolahan dan pembahasan data pengamatan upaya perbaikan sistem kerja untuk mengurangi waktu idle mesin potong otomatis Gerber di Departemen Cutting PT. TWI untuk order T-shirt Style W Train Tee, maka dapat ditarik kesimpulan sebagai berikut:

1. Proses bundling yang dimulai pada saat mesin potong selesai memotong panel dalam 1 bite dan proses bundling yang dilakukan bersamaan dengan perpindahan mesin serta persiapan kain untuk pemotongan berikutnya dapat mengurangi waktu idle mesin potong otomatis Gerber.

2. Upaya yang dapat dilakukan untuk mengurangi waktu idle mesin potong otomatis Gerber adalah melakukan perbaikan sistem kerja dengan menggabungkan atau melakukan beberapa proses secara bersamaan.

3. Perbaikan sistem kerja yang dilakukan dapat menurunkan waktu idle mesin sebesar 994,66 detik atau sama dengan 16,58 menit, yang sebelum pengaturan adalah sebesar 4.821,9 detik atau sama dengan 80,365 menit, 
menjadi $3.827,24$ detik atau 63,79 menit.

Selain berpengaruh terhadap waktu idle mesin, perbaikan sistem kerja juga mempengaruhi waktu penyelesaian menjadi lebih cepat. Selisih waktu penyelesaian sebelum dan sudah perbaikan sistem kerja sebesar 999,92 detik atau 16,67 menit. Waktu penyelesaian yang awalnya sebesar 9.496,65 detik menjadi 8.496,73 detik. 


\section{DAFTAR PUSTAKA}

1. Echols, John M., Hassan Shadily, Kamus Inggris - Indonesia, Gramedia Pustaka Utama, Jakarta, 1988.

2. Hudson, Peyton B., Guide to Apparel Manufacturing, North Carolina, 1989.

3. Iftikar Z. Sutalaksana, Teknik Perancangan Sistem Kerja, Bandung, ITB, 2006.

4. , GTxL GERBERcutter Applications Manual, 1999.

5. , Data Jumlah Produksi, Bagian Administrasi Pemotongan PT Trigoldenstar Wisesa, Karawang, 2013.

6. http:/google.co.id/perbaikansistemkerjaindustri, 20 Januari 2014.

7. http:/google.co.id/mengurangi-waktu-idle-untuk-meningkatkanproduktivitas, 20 Januari 2014. 